As-Syifaa Vol 09 (02) : Hal. 146-153, Desember 2017

ISSN : 2085-4714

\title{
ANALISIS KEPUASAN PELAYANAN OBAT PADA PASIEN DI PUSKESMAS BERSTANDAR ISO 9001:2008 DI DONGGALA KECAMATAN BANAWA
}

\author{
Sri Ayu Noviyanti, Alwiyah Mukaddas, Muhamad Rinaldhi Tandah \\ Jurusan Farmasi, Fakultas MIPA, Universitas Tadulako, Palu \\ Email: sriayu.noviyanti@yahoo.co.id
}

\begin{abstract}
Community health center is technical implementation unit of a district / municipality health service who are responsible for organizing health development in a working area. The aims of this study is to determine the relationship between drug services with the level of patient satisfaction at the pharmacy unit of Donggala community health center in Banawa subdistrict, and also to know the level of patient satisfaction and expectations by measuring with Importance Performance Analysis method to the five dimensions of service in the pharmacy unit at Donggala community health center of Banawa subdistrict. This research was conducted at the pharmacy unit of Donggala community health center in Banawa subdistrict on September 2016 until December 2016 by purposive sampling using questionnaire as instrument through Likert scale. Patient satisfaction are measured using 5 dimension of service which are tangible, relibility, responsiveness, assurance and empathy were analyzed by Importance Performance Analysis (IPA). As the result with 151 respondents at the average of gap (GAP) is -0.82 and $80.87 \%$ match rate and the most widely indicator were mapped by cartesius diagram is in quadrant $A$ which are the quality service must still be considered and improved. This is also shows patient in Donggala community health center are still less satisfied and their expectation are still below.
\end{abstract}

Key words: Patient satisfaction, importance performancde analysis, gap.

\section{PENDAHULUAN}

Kesehatan adalah salah satu kebutuhan dasar manusia. Sebagai kebutuhan yang mendasar, setiap orang mengharapkan pelayanan kesehatan yang bermutu. ${ }^{1}$ Selama ini, belum semua layanan puskesmas memberikan pelayanan bermutu yang bisa memberikan kepuasan kepada pasien. Salah satu pelayanan yang harus diperhatikan yaitu pelayanan obat yang termasuk pelayanan publik yang perlu diperhatikan sebab pelayanan obat mempunyai keterkaitan yang erat dengan masyarakat. Pelayanan obat akan berpengaruh pada kesejahteraan pasien atau masyarakat. $^{2}$

Puskesmas harus mampu mempertahankan kualitasnya dengan 
Analisis kepuasan pelayanan obat pada pasien di puskesmas berstandar ISO 9001:2008 di Donggala Kecamatan Banawa

memberikan pelayanan yang sesuai dengan harapan pasien sehingga konsumen merasa puas. Pengukuran kualitas jasa dalam model SERVQUAL didasarkan pada skala multi-item yang dirancang untuk mengukur harapan dan persepsi pelanggan, serta gap diantara keduanya dalam dimensidimensi utama kualitas jasa. Dimensi utama kualitas jasa tersebut adalah reliabilitas (reliability), daya tanggap (responsiveness), jaminan (assurance), empati (emphaty), dan bukti fisik (tangibles). ${ }^{3}$

Puskesmas

Donggala

Kecamatan Banawa merupakan puskesmas pertama yang menerima sertifikasi internasional dan telah menjadi Puskesmas berstandar ISO (International Organization for Srandardization) 9001:2008. ISO 9001;2008 adalah Pelayanan yang menggunakan Standart sistem manajemen mutu yang dikaitkan langsung dengan pelayanan kesehatan. Standar sistem manajemen mutu yang digunakan untuk menilai apakah sistem manajemen mutu dibakukan, dijalankan, dimonitor, dievaluasi dan diperbaiki terus menerus.

Hasil penelitian yang dilakukan oleh Gary (2012) menunjukkan bahwa nilai koefisien determinasi terhadap kepuasan pasien di RS Elim sebesar $52,7 \%{ }^{4} \quad$ Dimensi yang memiliki pengaruh yang signifikan terhadap kepuasan pasien yaitu dimensi Tangible, Reliability, Assurance, sedangkan dimensi yang tidak memiliki pengaruh yang signifikan terhadap kepuasan pasien yaitu Responsiveness dan Empati.

Berdasarkan uraian di atas, peneliti tertarik untuk melakukan penelitian tentang analisis kepuasan pelayanan obat pada pasien di puskesmas berstandar ISO 9001:2008 di Donggala Kecamatan Banawa.

\section{METODE PENELITIAN}

Jenis Penelitian

Jenis

penelitian

ini

merupakanpenelitian

survei yaitupenelitian yang memakai ukuran sampel dari suatu populasi dan melakukan pengamatan secara langsung pada obyek penelitian dengan instrument penelitian yang digunakan berupa kuesioner.

\section{Lokasi Penelitian}

Penelitian ini dilakukan di Apotek Puskesmas Donggala Kecamatan Banawa.

\section{Populasi dan Sampel}

Populasi penelitian adalah seluruh pengunjung/pasien yang 
Analisis kepuasan pelayanan obat pada pasien di puskesmas berstandar ISO 9001:2008 di Donggala Kecamatan Banawa

berkunjung ke puskesmas dan

1. Pasien berumur $17-60$ tahun

mendapatkan pengobatan di Apotek

Puskesmas Donggala Kecamatan

Banawa.

Pengambilan sampel dilakukan

dengan purposive sampling. Jumlah

sampel diambil berdasarkan jumlah

indikator penelitian dikalikan 5 yaitu 28

indikator $\times 5=140$ responden.

Pengambilan sampel didasarkan pada

kriteria inklusi dan eksklusi sebagai

berikut :

Kriteria inklusi sampel :

2. Pasien yang sedang menebus obat di pelayanan obat

Kriteria eksklusi sampel :

1. Pasien yang sedang sakit keras

2. Tidak bersedia untuk menjadi responden

3. Pasien buta huruf

HASIL PENELITIAN

Jumlah responden Apotek Puskesmas Donggala yang diteliti adalah 151 responden dengan karakterisitik responden dibawah ini:

Tabel 1. Karakteristik responden

\begin{tabular}{lcc}
\hline \multicolumn{1}{c}{ Data } & Frekuensi $(\mathbf{n}=\mathbf{1 5 1})$ & (\%) \\
\hline 1. Jenis kelamin & 43 & \\
Laki-laki & 108 & 72 \\
Perempuan & & \\
\hline 2. Umur & 16 & 11 \\
$\leq 20$ tahun & 61 & 40 \\
21 - 30 tahun & 35 & 2 \\
31 - 40 tahun & 25 & 17 \\
41 - 50 tahun & 14 & 9 \\
$51-60$ tahun & & 4 \\
\hline 3. Pendidikan terakhir responden & 6 & 12 \\
a.SD & 18 & 61 \\
b.SMP & 92 & 11 \\
c. SMA & 16 & 12 \\
d.Diploma (D1-D4) & 19 & 24 \\
e.Sarjana S1 dan S2 & 27 & 28 \\
\hline 4. Pekerjaan responden & 37 & 18 \\
a.PNS & 8 & 22 \\
b. Wiraswasta & 33 & 5 \\
c. Pelajar & 42 & 3 \\
d. Honorer & 4 & \\
e.URT & & \\
f. Mahasiswa & & \\
\hline
\end{tabular}


Analisis kepuasan pelayanan obat pada pasien di puskesmas berstandar ISO 9001:2008 di Donggala Kecamatan Banawa

Tabel 2. Nilai kesenjangan (gap) rata-rata dan tingkat kesesuaian tiap dimensi Servqual

\begin{tabular}{ccc}
\hline Dimensi SERVQUAL & Kesenjangan (gap) & Tingkat kesesuaian (\%) \\
\hline Tangible & -0.76 & 81.84 \\
Reliability & -0.75 & 82.37 \\
Responsiveneess & -1.00 & 76.85 \\
Assurance & -0.69 & 84.02 \\
Emphaty & -0.89 & 79.26 \\
Rata-rata & -0.82 & 80.87 \\
\hline
\end{tabular}

Tabel 3. Distribusi indikator-indikator pada tiap kuadran

\begin{tabular}{cl}
\hline Kuadran & \multicolumn{1}{c}{ Nomor Indikator } \\
\hline A & $3,4,7,10,11,12,13,14,15,16,17,18,19,23,24,25,26,28$ \\
B & $1,2,8,9,20,21,22,27$ \\
C & 5 \\
D & 6 \\
\hline
\end{tabular}

\section{PEMBAHASAN}

Berdasarkan karakteristik responden tabel 1 menunjukkan kelompok jenis kelamin terbesar yaitu perempuan dengan jumlah frekuensi 108 dan persentasi $72 \%$. Berdasarkan kisaran umur, kelompok umur yang tertinggi adalah 21-30 tahun dengan frekuensi 61 dan persentasi $40 \%$. Hal ini menunjukkan bahwa pasien pada umur 20-30 tahun lebih sering berobat di Puskesmas Donggala Kecamatan Banawa. Sedangkan untuk kelompok umur yang terendah adalah 51-60 tahun dengan frekuensi 14 dan persentasi $9 \%$. Berdasarkan frekuensi tingkat pendidikan yang tertinggi adalah SMA dengan jumlah frekuensi 92 dan persentasi 61\%. Sedangkan tingkat pendidikan terendah adalah $\mathrm{SD}$, dimana frekuensi 6 dengan persentasi $4 \%$. Berdasarkan frekuensi tingkat pekejaan yang tertinggi adalah URT (Urusan Rumah Tangga) dengan jumlah frekuensi 42 dan persentasi $5 \%$. Sedangkan tingkat pekerjaan terendan adalah pelajar dengan frekuensi 8 dan persentasi 18\%. Hal 
Analisis kepuasan pelayanan obat pada pasien di puskesmas berstandar ISO 9001:2008 di Donggala Kecamatan Banawa

ini disebabkan oleh banyaknya URT

yg perlu melakukan pengobatan di

Puskesmas Donggala karena kemungkinan seorang URT memiliki pekerjaan yang lebih banyak daripada tingkat pekerjaan seorang pelajar.

Rata-rata skor dimensi tingkat kesesuian tertinggi adalah pada dimensi assurance yang menggambarkan bahwa pengetahuan dari petugas hampir sesuai atau telah sesuai dengan yang diinginkan oleh responden. Sedangkan tingkat kesesuaian terendah adalah pada dimensi responsiveness artinya para petugas dalam membantu dan memberikan pelayanan dengan tanggap masih kurang sesuai. Hal ini disebabkan karena, petugas kurang tanggap dalam menanggapi apa yang menjadi inginan atau kebutuhan dari responden. Distribusi indikator-indikator pada tiap kuadran menunjukkan bahwa titik nilai rata-rata harapan pasien adalah 4,28 dan titik nilai rata-rata kenyataan adalah sebesar 3,46.

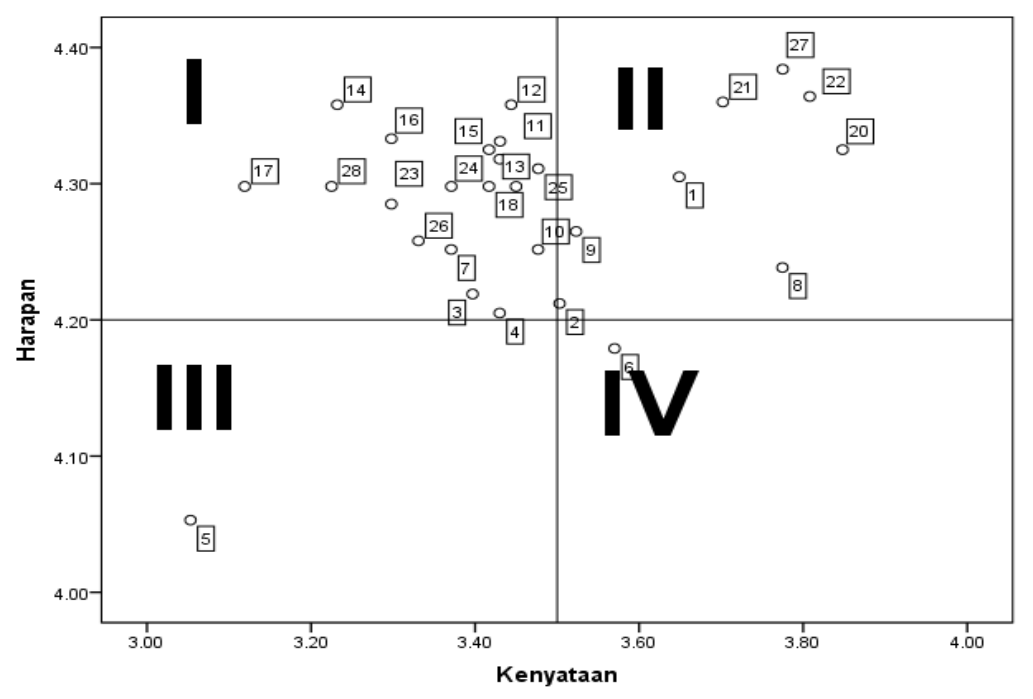

Gambar 1. Diagram kartesius dan faktor-faktor yang mempengaruh tingkat kepuasan paisen di apotek puskesmas Donggala Kecamatan Banawa

Rata-rata skor gap tertinggi adalah pada dimensi responsiveness yang menyatakan bahwa responden tidak puas terhadap pelayanan yang telah diberikan hal ini dikarenakan petugas tidak tanggap dalam membantu dan memberikan pelayanan dengan cepat pada responden. Sedangkan gap terendah adalah dimensi assurance dimana, responden sudah cukup puas terhadap kemampuan yang para petugas berikan pada responden, serta kesopanan yang para petugas 
Analisis kepuasan pelayanan obat pada pasien di puskesmas berstandar ISO 9001:2008 di Donggala Kecamatan Banawa

perlihatkan dalam melayani responden. Semakin tinggi gap, semakin jauh kenyataan yang diberikan dengan harapan yang diinginkan responden. Kuadran I yang menunjukkan bahwa faktor-faktor yang sangat penting tetapi kenyataan yang dilakukan tidak sesuai denga harapan. Dari hasil penelitian didapat 18 indikator yang mencakup semua dimensi masuk dalam kuadran I. Artinya secara bukti fisik, kehandalan, jaminan, empati, serta daya tanggap dalam memberikan informasi obat yang diberikan oleh apotek puskesmas belum memenuhi dari harapan yang diinginkan oleh responden.

Kuadran II menunjukkan fatorfaktor yang dianggap penting telah berhasil dilaksanankan sesuai denga harapan. Kuadran II terdapat 8 indikator. Dimana, pelayanan yang sudah sesuai dengan harapan responden serta yang dirasakan oleh responden adalah ruang tunggu yang bersih, rapi dan nyaman, kemasan obat yang diterima keadaannya baik, petugas yang melayani ramah, obat yang diberikan sudah sesuai dengan yang diresepkan, petugas menyiapkan obat dengan teliti dandalam keadaan yang baik serta bahasa yang digunakan mudah dipahami.
Kuadran III menunjukkan faktor yang dianggap kurang penting oleh pasien dan pelaksanaan yang dilakukan oleh Apotek Puskesmas Donggala Kecmata Banawa biasa saja aitu pada kelengkapan fasilitas ruang tunggu yang berupa kipas angin, TV, brosur. Hal ini sesuai dengan penelitian yang dilakukan oleh pusparia (2010) tentang hubungan tingkat kepuasan pasien rawat jalan terhadap pelayanan Instalasi Farmasi RSUD Budhi Asih di Depok. Kuadran III dianggap tidak penting karena kipas angin, TV dan brosur tidak menjadi keinginakan pasien dalam pengobatan kesehatan. $^{5}$

Kuadran IV menunjukkan faktor yang kurang penting, tetapi pelaksanaannya berlebihan/sangat memuaskan. Karena pakai seragam ataupun tidak pakai seragam itu tidak penting yang dibutuhkan hanya obatnya, tetapi mereka laksanakan dengan baik, karena pada SOP nya pada hari senin sampai jumat itu mereka harus pakai seragam. Artinya menurut pasien penampilan petugas apotek tidak menjamin kesembuhan bagi responden namun yang berpengaruh adalah pengunaan obat dan informasi obat. Sehingga menurut responden tidak mempengaruhi 
Analisis kepuasan pelayanan obat pada pasien di puskesmas berstandar ISO 9001:2008 di Donggala Kecamatan Banawa

kesehatan mereka. Tetapi karena puskesmas donggala sudah ada SOP bahwa petugas harus menggunakan seragam pada hari senin sampai hari jumat sehingga pelaksaannya yang dilakukan telah memuaskan sekali untuk penampilan petugas.

Puskesmas

Donggala

Kecamatan Banawa telah terstandarisasi ISO nomor 9001:2008. Standar ISO tersebut menggambarkan bahwa prosedur kerja sudah terstandar. Kalau sudah terstandar kepuasan pasien sudah baik tapi dalam penelitian ini didapatkan bahwa kepuasan pasien yang diukur menggunakan metode IPA didapat bahwa semua dimensi tidak sesuai dengan harapan responden atau tidak memuaskan pasien. Sejalan dengan penelitan yang telah dilakukan dengan rancangan cross-sectional menunjukkan bahwa kepuasan pasien pada layanan kesehatan berstandarisasi ISO lebih rendah daripada yang tidak berstandarisasi ISO, yang artinya kualitas manajemen ISO tidak mempengaruhi kepuasan pasien.

\section{KESIMPULAN}

1. Pelayanan obat pada dimensi tangible (bukti fisik), relibility (keandalan), responsiveness (tanggapan), assurance (jaminan), emphaty (empati) mempunyai hubungan dengan tingkat kepuasan pasien di Apotek Puskesmas Donggala Kecamatan Banawa.

2. Berdasarkan analisis metode IPA diperoleh nilai rata-rata kesenjangan (gap) yaitu $-0,82$ dengan tingkat kesesuaian 80,87 dan indikator yang terpetakan dalam diagram kartesius terbanyak yaitu pada kuadran A yang dimana kualitas pelayanan di Apotek Puskesmas Donggala Kecamatan Banawa harus diperhatikan dan diperbaiki. Sehingga dapat disimpulkan bahwa pasien masih kurang/tidak puas terhadap pelayanan yang diberikan.

\section{DAFTAR PUSTAKA}

1. Hamid R, Darmawansyah, Balqis. Hubungan Mutu Pelayanan Kesehatan dengan Kepuasan Pasien Rawat Jalan di Puskesmas Batua Kota Makasar". Available at: http://repository.unhas.ac.id/handle /123456789/5724 [diakses 18 februari, 2016].

2. Hatmoko. Sistem Pelayanan Kesehatan Dasar Puskesmas. Samarinda : Universitas Mulawarman; 2006.

3. Tjiptono F. Perspektif Manajemen dan Pemasaran Konterporer. Edisi 1. Yogyakarta : Penerbit Andi,; 2000. 
Analisis kepuasan pelayanan obat pada pasien di puskesmas berstandar ISO 9001:2008 di Donggala Kecamatan Banawa

4. Leonard, Gary. Analisis Pengaruh Kualitas Layanan Terhadap Kepuasan Pasien Pada Rumah Sakit Elim Kab. Toraja Utara. Makassar : Universitas Hasanuddin; 2012.
5. Pusparia L. Analisis Hubungan Tingkat Kepuasan Pasien Rawat Jalan Terhadap Pelayanan Instalasi Farmasi Dengan Minat Pasien Menebus Kembali Resep Obat Di Instalasi Farmasi RSUD Budhi Asih Tahun 2010 (Tesis) Jakarta:Universitas Indonesia; 2010. 